\title{
Compulsory Licensing and Public Health
}

Citation for published version (APA):

Kamperman Sanders, A. W. J. (2004). Compulsory Licensing and Public Health. Maastricht Journal of European and Comparative Law, 4, 337-346. https://doi.org/10.1177/1023263X0401100401

Document status and date:

Published: 01/01/2004

DOI:

10.1177/1023263X0401100401

Document Version:

Publisher's PDF, also known as Version of record

Document license:

Taverne

\section{Please check the document version of this publication:}

- A submitted manuscript is the version of the article upon submission and before peer-review. There can be important differences between the submitted version and the official published version of record.

People interested in the research are advised to contact the author for the final version of the publication, or visit the DOI to the publisher's website.

- The final author version and the galley proof are versions of the publication after peer review.

- The final published version features the final layout of the paper including the volume, issue and page numbers.

Link to publication

\footnotetext{
General rights rights.

- You may freely distribute the URL identifying the publication in the public portal. please follow below link for the End User Agreement:

www.umlib.nl/taverne-license

Take down policy

If you believe that this document breaches copyright please contact us at:

repository@maastrichtuniversity.nl

providing details and we will investigate your claim.
}

Copyright and moral rights for the publications made accessible in the public portal are retained by the authors and/or other copyright owners and it is a condition of accessing publications that users recognise and abide by the legal requirements associated with these

- Users may download and print one copy of any publication from the public portal for the purpose of private study or research.

- You may not further distribute the material or use it for any profit-making activity or commercial gain

If the publication is distributed under the terms of Article $25 \mathrm{fa}$ of the Dutch Copyright Act, indicated by the "Taverne" license above, 


\section{HEINONLINE}

DATE DOWNLOADED: Mon Sep 13 05:12:01 2021

SOURCE: Content Downloaded from HeinOnline

Citations:

Bluebook 21st ed.

Anselm Kamperman Sanders, Compulsory Licensing and Public Health, 11 Maastricht J. EUR. \& COMP. L. 337 (2004).

ALWD 6th ed.

Kamperman Sanders, A. ., Compulsory licensing and public health, 11(4) Maastricht J. Eur. \& Comp. L. 337 (2004).

APA 7th ed.

Kamperman Sanders, A. (2004). Compulsory licensing and public health. Maastricht Journal of European and Comparative Law, 11(4), 337-346.

Chicago 17th ed.

Anselm Kamperman Sanders, "Compulsory Licensing and Public Health," Maastricht Journal of European and Comparative Law 11, no. 4 (2004): 337-346

McGill Guide 9th ed.

Anselm Kamperman Sanders, "Compulsory Licensing and Public Health" (2004) 11:4 Maastricht J Eur \& Comp L 337.

AGLC 4th ed.

Anselm Kamperman Sanders, 'Compulsory Licensing and Public Health' (2004) 11(4) Maastricht Journal of European and Comparative Law 337.

MLA 8th ed.

Kamperman Sanders, Anselm. "Compulsory Licensing and Public Health." Maastricht Journal of European and Comparative Law, vol. 11, no. 4, 2004, p. 337-346.

HeinOnline.

OSCOLA 4th ed.

Anselm Kamperman Sanders, 'Compulsory Licensing and Public Health' (2004) 11

Maastricht J Eur \& Comp L 337

Provided by:

Maastricht University Library

-- Your use of this HeinOnline PDF indicates your acceptance of HeinOnline's Terms and Conditions of the license agreement available at https://heinonline.org/HOL/License

-- The search text of this PDF is generated from uncorrected OCR text.

-- To obtain permission to use this article beyond the scope of your license, please use: Copyright Information 


\section{Editorial}

\section{Compulsory Licensing and Public Health}

Compulsory licensing of patented pharmaceuticals has been a controversial issue for quite some time. The AIDS drugs war was fought in public in the global media as much as through WTO lobbying by NGO's and the Governments of South Africa and Brazil on the one side, and major drugs companies and the industrialized nations on the other. It has made the general public aware that drugs companies prefer to target the backpacker generation rather than developing nations when it comes to making available muchneeded medication for diseases such as encephalitis, malaria and tuberculosis. Although less than $5 \%$ of the drugs on the WHO Essential Drugs List ${ }^{2}$ are patented ${ }^{3}$ and patent protection in many developing countries is less stringent than TRIPS otherwise requires, ${ }^{4}$ the drugs are still not available. The Doha WTO Ministerial Declaration on TRIPS and Public Health of 14 November 2001 (WT/MIN(01)/DEC/2) was meant to increase access to essential drugs by allowing generic drugs manufacturers to produce medicine under a compulsory licence on the premise that this would increase production and lower prices. At the time it was recognised that the provisions of the TRIPS Agreement stood in the way of production and sale under compulsory licence of patented

1. See also A. Kamperman Sanders, 'Patents - Antitrust, Compulsory Licensing and Research Exceptions', in Heath/Kamperman Sanders (eds.), Industrial Property in the Bio-Medical Age (Kluwer Law International, 2003), 163-184.

2. See $<\mathrm{http}: / / \mathrm{www}$.who.int/medicines/organization/par/edl/procedures.shtml $>$ for the selection criteria of essential medicines, which do not include the patent status of the drug in question, but does give consideration to cost, thus potentially excluding therapeutically important but expensive drugs; for the list see http://mednet3.who.int/eml/eml_intro.asp. See also Velásquez, 'Phamaceutical Patents and Accessibility to Drugs', Revue Internationale de Droit Economique Special Edition: Pharmaceutical Patents, Innovations and Public Health (2001), 41 and Dumoulin, 'Patents and the Price of Drugs', Revue Internationale de Droit Economique Special Edition: Pharmaceutical Patents, Innovations and Public Health (2001), 49.

3. IFPMA Press Release, Geneva, 20 December 2001, available at $<$ http://www.ifpma.org $>$.

4. The Doha WTO Ministerial Declaration on TRIPS and Public Health of 14 November 2001 (WT/MIN(01)/DEC/2) reiterates that the least developed members are exempted from implementing, employing and enforcing pharmaceutical product and test data protection and may refrain from granting exclusive marketing protection during the period patent protection is not provided until 1 January 2016, see <http://www.wto.org >. 
pharmaceutical products for the purpose of export to third countries with no or insufficient manufacturing capacity in the pharmaceutical sector. The WTO General Council Decision of 30 August 2003 on the Implementation of Paragraph 6 of the Declaration of the TRIPS Agreement and Public Health ${ }^{5}$ allows WTO Members to waive the obligation under Article 31(f) TRIPS Agreement to limit such production to the needs of domestic markets only. Now that WTO members are about to implement the WTO General Council Decision on Public Health, it is time to ask whether this is the necessary breakthrough for large-scale dissemination of low-priced pharmaceuticals and how the EU intends to give effect to the Decision.

\section{$\S 1$. Compulsory Licensing under TRIPS}

The WTO Agreement on Trade Related Aspects of Intellectual Property Rights (TRIPS Agreement) offers WTO members a broad discretion on government use of compulsory licensing. There are no limitations on the grounds upon which a government can authorize use of a patent by third parties. Grounds enunciated in Art. 31 TRIPS are cases of national emergency, anti-competitive practices, public non-commercial use and dependent patents. Further grounds can be found in Art. 8(1), which allows members to adopt measures necessary to protect public health and nutrition, and to promote the public interest in sectors of vital importance to their socio-economic and technological development. Furthermore Art. 8(2) permits members to take necessary measures to prevent the abuse of intellectual property rights by right holders or the resort to practices that unreasonably restrain trade or adversely affect the international transfer of technology. There are, however, a number of procedural requirements that can be summarized as follows:

1. Cases have to be judged on their individual merits, thus excluding blanket advance approval for patents in a particular field of technology; ${ }^{6}$

2. Prior to authorizing third party use there should be an effort to negotiate a voluntary licence on reasonable commercial terms;

3. Government must provide for adequate remuneration, taking into account the economic value of the authorization; and

4. Use shall be authorized predominantly for the supply of the domestic market;

5. The scope and duration of the licence is limited to the purpose for which it was authorized, a requirement which is supplemented by the 'Intel clause', limiting the licensing of semiconductor technology to public non-commercial use and judicial remedies for anti-competitive behaviour;

5. WT/L/540 of 2 September 2003.

6. Further reinforced by Art. 27(1), which states that patents shall be available and patent rights enjoyable without discrimination as to the place of invention, the field of technology and whether products are imported or locally produced. 
6. Licences must be terminated if and when the circumstances, which led to it, cease to exist and are unlikely to recur.

Exemptions can be found in Art. 31(b), which allows a waiver of the requirements for negotiation for a voluntary licence on reasonable commercial terms in case of

1. A national emergency or other circumstances of extreme urgency; or

2. In cases of public non-commercial use.

Article 32 provides that there should be an opportunity for judicial review of any decision to revoke or forfeit a patent.

\section{$\S 2$. Public Health and TRIPS Compliance}

Two nations have been at the forefront of sparking off an international row over the compulsory licensing of pharmaceuticals. South Africa and Brazil both had, and to some extent continue to have, in place legislation that can be used to go beyond the possibilities under TRIPS to grant compulsory licenses.

\section{A. SOUTH AFrICA}

South Africa's policy towards medical products has been controversial as the health minister previously enjoyed unfettered discretion to set aside any domestic or international patent obligations deemed to stand in the way of the people's welfare. ${ }^{7}$ It was thus possible to expand the scope for compulsory licensing and parallel imports of medicines in South Africa beyond TRIPS limitations. On 18 February 1998, a group of 39 pharmaceutical companies joined the South African Pharmaceutical Manufacturers Association (PMA) suit against the government of South Africa with the aim of trying to stop this practice. On 6 May 2001, the South African court adjourned the case, bowing to threats from the PMA to file an appeal on the grounds that they needed additional time to response to the new evidence and issues raised by Treatment Access Campaign (TAC), an organization that had been given amicus curiae status. By that stage, however, the controversy had been exposed to world-wide press coverage, delivering a public-relations disaster for the pharmaceutical companies. Their argument that the price of drugs is not the main problem for third world healthcare systems but rather the poor state of healthcare in these nations itself, fell on deaf ears. ${ }^{8}$ Since then, the pharmaceutical companies themselves have been engaged in a 'face-restoring' price war, trying to outbid each other and generic drugs manufacturers to supply cheaper

7. For a complete overview see the South Africa dossier on the Consumer Project on Technology internet pages, available at $<\mathrm{http} / /$ www.cptech.org/ip/health/sa/ $>$.

8. Denny, 'Patently absurd', Guardian - Unlimited, 9 April 2001, available at <http://www.guardian.co uk/Archive/Article/0,4273,4167490,00.html>. 
AIDS drugs to Africa, ${ }^{9}$ lowering prices to $\$ 500$ per patient per year. On 3 February 2003, the South African Competition Commission heard a complaint against Glaxo Smith Kline and Boehringer Ingelheim over excessive pricing of essential AIDS medication. The ongoing pressure to lower prices is likely to continue, as new medical developments and the need for multiple (cocktail) drug use results in prices that are still beyond the means of many HIV patients.

\section{B. BRAZIL}

Brazil's policy on compulsory licensing has been controversial for a long time. ${ }^{10}$ The Brazilian Patent Act provides for two options for compulsory licensing." The first applies when the production of a particular patent is not carried out in Brazil within a period of three years upon registration of the patent. Non-working also comprises the incomplete manufacture or use of a process. ${ }^{12}$ The patent holder can justify his inaction on legitimate reasons stemming from grounds of economic unfeasibility. However, commercialization short of market demand is also deemed to be non-working. ${ }^{13} \mathrm{~A}$ working of the patent in Brazil that does not satisfy market demand may therefore be considered sufficient grounds for the granting of a compulsory licence.

Section 68 of the Brazilian Patent Act has been the bone of contention in a longstanding trade dispute between the U.S. and Brazil. On 1 February 2001, a WTO panel was established to hear the case. ${ }^{14}$ The U.S. position is that the compulsory licensing provision for non-working is in violation of Art. 27(1) TRIPS, which prohibits Members of the WTO from requiring the local production of the patented invention as a condition for enjoying exclusive patent rights. The United States asserts that the "local working" requirement contained in the Brazilian Patent Act can only be satisfied by the local production - and not the importation - of the patented subject-matter. This position is fuelled by the impression that working of the patent needs to take place in the territory of Brazil. Furthermore, the U.S. takes issue with the fact that failure to work the patent also comprises incomplete manufacture of the product or a failure to make full use of the patented process. In the public relations battle Brazil put itself

9. Pilling, 'Rivals in race to cut price of Africa's Aids drugs', Financial Times - FT.com, 14 March 2001, available at http://news.ft.com/.

10. For a complete overview see the Brazil dossier on the Consumer Project on Technology internet pages,

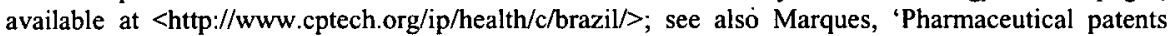
and Drug Accessibility in Brazil', Revue Internationale de Droit Economique Special Edition: Pharmaceutical Patents, Innovations and Public Health (2001), 97 and Shanker, 'Brazil, The Pharmaceutical Industry and the WTO', Vol. 5 Journal of World Intellectual Property (2002) 53.

11. Brazil's industrial property law (Law No. 9,279 of 14 May 1996; effective May 1997)

12. B. Barbosa, 'The New Brazilian Patent Law', available at $<$ http://www.nbb.com.br/ip/pat8.html $>$ (as visited 06-06-2001).

13. See Bodenhausen, Guide to the Application of the Paris Convention for the Protection of Industrial Property, BIRPI (1968).

14. WT/DS199/1. 
ahead of the game in that it capitalized on the AIDS drugs patent dispute in South Africa $^{15}$ and brought its own National STD/AIDS Programme to the attention of the world. ${ }^{16}$ Ultimately Brazil managed to get a resolution adopted by the UN Commission of Human Rights on the right of access to medication. ${ }^{17}$ The 53-member body passed the resolution by a 52-0 vote, with the United States abstaining. The blanket effect of Section 68 of the Brazilian patent act is, however, likely to present a problem, as can be clearly seen from the U.S. reaction to Brazil's manoeuvres:

'Since the establishment of this panel, however, Brazil has asserted that the U.S. case will threaten Brazil's widely-praised anti-AIDS program, and will prevent Brazil from addressing its national health crisis. Nothing could be further from the truth. For example, should Brazil choose to compulsory licence anti-retroviral AIDS drugs, it could do so under Section 71 of its patent law, which authorises compulsory licensing to address a national health emergency, consistent with TRIPS, and which the United States is not challenging. In contrast, Section 68 - the provision under dispute - may require the compulsory licensing of any patented product, from bicycles to automobile components to golf clubs. Section 68 is unrelated to health or access to drugs, but instead is discriminating against all imported products in favour of locally produced products. In short, Section 68 is a protectionist measure intended to create jobs for Brazilian nationals. ${ }^{, 18}$

The fact that the Section 71 procedure is open to Brazil under its own patent act indeed does not strengthen their position. It is not surprising then that in the wake of the Doha Ministerial Declaration on TRIPS and Public Health a mutually agreed solution ${ }^{19}$ was presented on 19 July 2001, amounting to prior US approval to any compulsory licensing on Brazil's part in respect of compulsory licenses on patents held by US companies. Brazil, however, is keeping up the pressure and in 2003 started with the parallel

15. See South Africa above. See also Seeman 'Patently Wrong', National Review, 21 March 2001, $<\mathrm{http}: / / \mathrm{www}$.nationalreview.com/nr_comment/nr_commentprint032101a.html> (as visited 19-042001); Mutetwa, 'HIV/AIDS: is Zimbabe doing enough?', Financial Gazette 26 April 2001, <http://www. fingaz.co.zw/fingaz/2001/April/April 26/1429.shtml> (as visited 31-05-2001), Reuters, 'Cuba backs Brazil in AIDS drugs patent dispute', 3 April 2001, and 'Cuba seeks Third World challenge to patent rules', <http://news.findlaw.com/legalnews/s/20010323/cubausapatents.html>.

16. See Commission on Intellectual Property Rights, Integrating Intellectual Property Rights and Development Policy (2002, London, CIPR) at 43, available at $<\mathrm{http}: / / \mathrm{www}$.iprcommission.org $>$.

17. See the UN Commission on Human Rights resolution Access to Medication in the Context of Pandemics Such As HIV/AIDS of 23 April 2001, which was proposed by Brazil. Available at $<$ http://www.unhchr.ch/>.

18. U.S. Special 301 report, 2001, <http://www.ustr.gov/enforcement/special.pdf $>$.

19. WT/DS199/4, available at <http://www.wto.org $>$, which contains an insightful letter from Mr. Peter F. Allgeier, Executive Office of the President, Deputy United States Trade Representative to Mr. José Alfredo Graça Lima, Under-Secretary-General for Integration, Economic and External Trade Matters, Ministry of Foreign Affairs, Brazil, dated 25 June 2001. 
importation of patented pharmaceuticals under compulsory licences from India and China because of the continuing high prices of drugs from the big drugs manufacturers. Big Pharma was quick to react and negotiated a deal with the Brazilian government, resulting in lower prices for essential AIDS drugs. ${ }^{20}$

\section{WTO ACTION}

At the WTO Doha Ministerial Conference of November 2001 in Quatar, consensus on the compulsory licensing issue was seen as imperative for the successful conclusion of a new round of world trade negotiations. ${ }^{21}$ Due to the continuing controversy over antiretroviral AIDS drugs and the Anthrax crisis in the USA a breakthrough was possible and resulted in a joint declaration on the TRIPS Agreement and Public Health. ${ }^{22}$ The Ministerial Declaration amounts to an understanding that, members will not bring action before the WTO Dispute Settlement Board over compulsory licensing of essential patented drugs. ${ }^{23}$ It also reiterated that the least developed country Members $^{24}$ will not be obliged, in respect to pharmaceutical products, to implement the patent section ${ }^{25}$ or to enforce rights provided for under these sections before 1 January 2016 , thus alleviating any pressure on the compulsory licensing issue. ${ }^{26}$ The Ministerial Declaration hinges on the interpretation of TRIPS Article 8(1) and its exception for the institution of measures necessary ${ }^{27}$ to protect public health that are consistent with the

20. See Jordan, 'Brazil to Stir Up AIDS-Drug Battle: Nation to Authorize Imports of Generics, Citing the Cost of Big Companies' Drugs', Wall Street Journal, 5 September 2003; BBC News 18 November 2003, 'New Anti-HIV Drug Deal for Brazil', available at http://news.bbc.co.uk/1/hi/world/americas/ 3281683.stm.

21. Moore, director-general of the WTO, indicated in a statement that 'resolving the TRIPS and public health issue might be the 'deal-breaker' for a new trade round', see Banta, 'Public Health Triumphs at WTO Conference', 286 Journal of the American Medical Association, 2655 (2001), 2656, available at http://jama.ama-assn.org/issues/v286n21/fpdf/jmn1205.pdf .

22. Adopted on 14 November 2001, WT/MIN(01)/DEC/2, 20 November 2001.

23. Vandoren, 'Médicaments sans Frontières? Clarification of the Relationship between TRIPS and Public Health resulting from the WTO Doha Ministerial Declaration', 5 Journal of World Intellectual Property (2002); and Abbott, 'The TRIPS Agreement, Access to Medicines, and the WTO Doha Ministerial Conference', 5 Journal of World Intellectual Property (2002).

24. For a list of least developed countries see <http://www.unctad.org/Templates/webflyer.asp?docid= 2929\&intItemID=1634\&lang=1>.

25. Section 5 TRIPS Agreement.

26. On the issue of the role of the patent system as a motivator or hindrance to innovation in the pharmaceutical area see Muennich, 'Pharmaceutical Patents and Availability of Drugs', Revue Internationale de Droit Economique Special Edition: Pharmaceutical Patents, Innovations and Public Health 73 (2001) and Mossinghoff, 'The Importance of Intellectual Property Protection to the American Research-Intensive Pharmaceutical Industry', 31 The Columbia Journal of World Business 38 (1996).

27. See Canada, where stockpiling of drugs in the last six months of patent term was permitted. Rogers, 'The Revised Canadian Patent Act, the Free Trade Agreement, and Pharmaceutical Patents: An Overview of Pharmaceutical Compulsory Licensing in Canada', [1990] 10 EIPR 351. See WTO Dispute Settlement Body Panel Report in Canada - Patent Protection of Pharmaceutical Products WT/DS1 14/R of 25 April 2000. Canada had to comply with the DBS's rulings and recommendations by 12 August 2001 , abolishing the stockpiling practice. 
TRIPS provisions. ${ }^{28}$ In the face of adversity (the U.S. and Big Pharma tried to limit the scope of the Declaration to drugs for the treatment of HIV/AIDS, tuberculosis and malaria) the WTO members took some two years to agree on measures that would lead to a satisfactory arrangement to give effect to the Declaration. The supply of essential drugs under compulsory licences to least-developed WTO members and WTO members with insufficient or no manufacturing capacity in the pharmaceutical sector was finally guaranteed in the WTO General Council Decision on the Implementation of Paragraph 6 of the Declaration of the TRIPS Agreement and Public Health, which is based on a EU proposal. The Decision will see the WTO begin to routinely review the issuance of individual licences for pharmaceutical products and will look at the terms of individual licenses. It will evaluate the basis for deciding manufacturing capacity is insufficient, or reviewing any of the new terms and obligations for the issue compulsory licences of patents on medicinal products.

\section{CONTROL OF PARALLEL IMPORTS AND EXHAUSTION OF RIGHTS}

The WTO General Council Decision is essentially based on differential pricing, ${ }^{29}$ rather than an overhaul of the patent system: 'Differential pricing of essential drugs is fully compatible with the TRIPS Agreement and should not require countries to forego any flexibility they have under it. ${ }^{30}$ Differential pricing allows companies producing patented drugs to recover most of the costs of R\&D in the developed nations, while at the same time selling or licensing production at lower prices in lower-income countries. Critical for the success of this operation is preventing parallel imports of cheap drugs into developed markets. ${ }^{31}$ Since the TRIPS Agreement ${ }^{32}$ presently places the issue of exhaustion of rights outside of the ambit of WTO activity, ${ }^{33}$ a shift from compulsory

28. See Art. 27(1) TRIPS, which states that any measures adopted cannot discriminate as to the place of invention, the field of technology and whether products are imported or locally produced; and also Art. XX of GATT 1994, indicating that any measures under TRIPS necessary to protect health also cannot amount to 'arbitrary or unjustifiable discrimination between countries where the same conditions prevail, or a disguised restriction on international trade'.

29. Sùbramanian, 'The AIDS Crisis, differential Pricing of Drugs, and the TRIPS Agreement - Two Proposals', 5 Journal of World Intellectual Property 323 (2001).

30. WTO press release of 11 April 2001 on the workshop on affordable medicines for poor countries, announcing a TRIPS Council discussion on intellectual property and access to drugs in June 2001 <http://www.wto.org/english/news_e/press01_e/pr220_e.htm> (as visited 19-04-2001), as well as the Report of the Workshop on Differential Pricing and Financing of Essential Drugs, Norwegian Foreign Affairs Ministry, Global Health Council 8-11 April 2001, Høsbjør, Norway, available at <http://www. wto.org/english/tratop_e/TRIPS_e/tn_hosbjor_e.htm\#finalreports $>$.

31. Pharmaceutical companies are themselves active, albeit for different reasons, to in preventing price differentiations within developed countries. See Pilling, Financial Times 11 June 2001, on the stance taken by pharmaceutical companies against price controls on prescription drugs in France. Following price control announcements, Pfizer and Aventis have threatened to reduce their presence in France in favour of relocation to the U.S., where $60 \%$ of their profits are made.

32. See Art. 6 TRIPS.

33. Art. 6 TRIPS removes the member states' provisions on exhaustion from the scope of the dispute settlement process of GATT, with the exception of the impact of Article 3 TRIPS, which provides for 
licensing to control of all parallel imports seems not very fruitful. Furthermore, there is the danger of erecting product-related trade barriers, singling-out one industry. The paradox, of course, is that the same developing countries that argue in favour of international exhaustion and ask for import restrictions into developed markets to be lifted have an interest in seeing parallel imports of cheap generic drugs into developed nations stopped. Universal international exhaustion of intellectual property rights would prevent price differentiation and be to the detriment of low-income countries. It is clear that the profit-maximising price for a patented product in a low-income country is lower than in a high-income country. In Japan, ${ }^{34}$ the U.S., ${ }^{35}$ and some European Countries, ${ }^{36}$ patent rights for sales outside of their territories are generally not deemed to be exhausted, although in some jurisdictions exhaustion may be implied. ${ }^{37}$ Similarly, trade mark rights are also mooted as enablers for the prevention of parallel trade. Market segmentation of first and third world markets through branding of drugs could contribute to the drug manufacturer's hold over the market. This makes it possible for the patent or trade mark owner to make a sale abroad and preclude on the basis of its domestic patent the importation of that product into the 'home country'.

\section{$\S 3$. Compulsory Licenses for Export and Prevention of Re-importation in the $\mathrm{EU}$}

In the EU the principle of free movement of goods and services within the internal market is safeguarded. ${ }^{38}$ The principle of Community Exhaustion ${ }^{39}$ is, however, employed in respect of goods produced or sold outside the EU. It is for this reason that

$\rightarrow$

national treatment, and Article 4 TRIPS, which imposes a duty on a member to apply the same rules of exhaustion in its external relations with other members.

34. Kabushi Kaisha \& Anor. V. BBS Kraftfahrzeug Technik A.G., Japanese Supreme Court, 1 July 1997, case no.95 (0) 1988.

35. Adelman, 'The Exhaustion Doctrine in American Patent Law' in Molengrafica, Grosheide/BoeleWoelki (eds.), Opstellen over Internationale Transacties en Intellectuele Eigendom (Vermande, 1997); Adelman, Rader, Thomas, and Wegner, Cases and Materials on Patent Law, (West Group, 1998), 1285-6.

36. Germany, the Netherlands and Italy; see Schatz, 'The Exhaustion of Patent Rights in the Common Market', 2 Int. Rev. Indus. Prop. \& Copyright L. 1 (1972); see, however, the European Court of Justice in Merck \& Co. v. Primecrown Ltd. [1995] F.S.R. 909.

37. Exemplifying this point, see for the latest state of affairs in the UK, Wilkinson [1997] 6 EIPR 319, commenting critically upon Roussel Uclaf v. Hockley International Ltd. [1996] 14 RPC 441, which established at 445 that a limited licence ('FOR USE IN THE PRC ONLY. RE-EXPORT FORBIDDEN') was only enforceable against a defendant if notice was brought to the attention of every person down the chain of supply.

38. Joined Cases C-427/93, C-429/93 and C-436/93 Bristol-Myers Squibb v. Paranova A/S C.H. Boehringer Sohn, Boehringer Ingelheim KG, Boehringer Ingelheim A/S v. Paranova A/S Bayer Aktiengesellschaft, Bayer Danmark $A / S$ v. Paranova $A / S$ [1996] 1 ETMR 1, 20, para. 75; and Joined Cases C-267-268/95 Merck \& Co Inc and Others v. Primecrown Limited and Others, [1997] 1 CMLR 83. On the Paranova cases see Shea [1997] 3 EIPR 103; and Castillo de la Torre [1997] 6 EIPR 304.

39. Case C-355/96 Silhouette International Schmied GmbH v. Hartlauer Handelsgesellschaft mbH, 2 C.M.L. Rev. 953 (1998). 
the Proposed European Parliament and Council Regulation on compulsory licensing of patents relating to the manufacture of pharmaceutical products for export to countries with public health problems seeks to provide a uniform implementation of the WTO General Council Decision, also with a view to prevent re-importation into the EU of pharmaceuticals manufactures under compulsory licences. ${ }^{40}$

In order for WTO members to qualify for the grant of a compulsory licence for the purpose of importation of drugs from the EU, an application needs to be supported by a notification to the WTO in respect of the patented products covered by it. Names and quantities of the drugs in question need to be submitted, and the lack of own manufacturing capacity needs to be demonstrated. Least-developed WTO members benefit from a presumption of insufficient manufacturing capacity. The proposal's objective is to safeguard the limited application of compulsory licensing in that the applicant country has to provide evidence that it has made reasonable efforts to obtain authorization from the right holder on reasonable terms and conditions and that these efforts have not been successful within a reasonable period of time. A national emergency or other circumstances of extreme urgency shall be taken into account in the assessment of what constitutes a reasonable period of time. The compulsory licence has to comply with strict limitations and conditions on production, selective distribution, marking, labelling, packaging, numbering and recordkeeping. The WTO has to be notified and all information has to be made available on a website for the purpose of informing competent authorities, especially customs officials, which consignments cannot be imported into the Community. As such drugs produced under compulsory licence for the purpose of export should fall under Regulation 1383/2003 on customs action against goods suspected of infringing intellectual property rights, the reimportation of drugs produced under a compulsory licence for the purpose of export to least-developed WTO members, or members with insufficient production capacities can be prevented. ${ }^{41}$ The compulsory licence must be terminated as soon as possible, according to the proposal, and decisions to grant compulsory licences are subject to judicial review.

40. Proposal for a Regulation of the European Parliament and of the Council on compulsory licensing of patents relating to the manufacture of pharmaceutical products for export to countries with public health problems COM (2004) 737; For similar proposals in Canada, see Bill C-9, An Act to amend the Patent Act and the Food and Drugs Act (The Jean Chretien Pledge to Africa), 3d sess., 37th Parl., 2004 and the 'Regulations Amending the Food and Drugs Regulations, (1402 - Drugs for Developing Countries', Canada Gazette Vol. 138, No. 40 - October 2, 2004, pp. 2748-2760.

41. Council Regulation $1383 / 2003$ of 22 July 2003 concerned customs action against goods suspected if infringing certain intellectual property rights and the measures taken against goods found to have infringed such rights, OJ L196/7. 


\section{$\S 4$. Conclusion}

Implementation of the WTO General Council Decision is well under way in the EU. The proposed directive will facilitate $\mathrm{EU}$ industry in producing under compulsory licence for countries that have no or insufficient production capacity. The proposal will not alter the fact that many needy patients will still not be able to afford even the lowerpriced medicine, but that the threat of compulsory licensing has a downward effect on prices is surely good news. Ultimately, however, the proposed directive has the effect that production capacity is not likely to expand in least-developed WTO members, let alone non-WTO members that are the least-developed nations. Transfer of both technology and aid remains necessary to alleviate the needs of millions affected by serious epidemics.

Anselm Kamperman Sanders 